\title{
HUDEMANN, Rainer, Stätten grenzüberschreitender Erinnerung. Spuren der Vernetzung des Saar-Lor-Lux- Raumes im 19. und 20. Jahrhundert
}

Denis Laborde

\section{(2) OpenEdition \\ Journals}

Édition électronique

URL : http://journals.openedition.org/ifha/1084

DOI : $10.4000 /$ ifha. 1084

ISSN : 2198-8943

Éditeur

IFRA - Institut franco-allemand (sciences historiques et sociales)

Référence électronique

Denis Laborde, "HUDEMANN, Rainer, Stätten grenzüberschreitender Erinnerung. Spuren der Vernetzung des Saar-Lor-Lux-Raumes im 19. und 20. Jahrhundert », Revue de I'IFHA [En ligne], Date de recension, mis en ligne le 01 janvier 2003, consulté le 22 septembre 2020. URL : http://journals.openedition.org/ifha/ 1084 ; DOI : https://doi.org/10.4000/ifha.1084

Ce document a été généré automatiquement le 22 septembre 2020.

(CIFHA 


\title{
HUDEMANN, Rainer, Stätten grenzüberschreitender Erinnerung. Spuren der Vernetzung des Saar-Lor- Lux-Raumes im 19. und 20. Jahrhundert
}

\author{
Denis Laborde
}

Ce CD-Rom est une publication institutionnelle qui prend place dans le cadre du projet Interreg II " Liens historiques et identité culturelle dans l'espace Sarre-Lor-Lux aux XIXe et XXe s. Villes et cultures urbaines aux XIXe et XXe s. ", subventionné par l'Union européenne et mené conjointement par les universités de Metz, de Nancy II, de Sarre et le Centre universitaire du Luxembourg. Les modifications incessantes des tracés de frontières à l'intérieur de l'espace Sarre-Lor-Lux (qui, depuis la fin des années 60 délimite, en gros, le Palatinat occidental, l'Alsace du Nord, la Wallonie et la région de Trèves, voire la Rhénanie-Palatinat dans son ensemble) et les conflits violents qui les ont accompagnées ont en même temps généré un brassage des populations qui, dans la période actuelle d'une construction européenne, est volontiers investi d'un caractère exemplificateur, la région s'attribuant un rôle de pionnier européen en matière d'interpénétrations transfrontalières. Cependant, cette région porte des traces collectives communément partagées que ce projet entend dépister, pour l'essentiel dans les édifices architecturaux envisagés ici comme les traces topographiques tangibles dans lesquelles se lit l'histoire de cette Lotharingia médiévale. Les premiers résultats de cette enquête sont fournis dans ce CDRom qui se présente comme une introduction au site internet du projet, où sont concentrés quelque 200 contributions organisées en neuf domaines de recherche et relatives à la culture ouvrière, syndicale et politique, à l'évolution des villages, aux lieux commémoratifs et aux monuments, à l'architecture industrielle, à l'infrastructure et à l'architecture des transports, à l'architecture de la culture et des loisirs, à l'architecture militaire et frontalière, aux édifices religieux et enfin à l'urbanisme. À chacun, ensuite, de consulter le site du projet : http :// www.memotransfront.uni-saarland.de. 
Denis LABORDE 